\title{
Issues in the Integration of Educational Technology into English Language Teaching Programme: An Empirical Study
}

\author{
Md. Maksud Ali*
}

\begin{abstract}
Technology, as everybody will agree, is increasingly getting involved in language education. In teaching English as an International Language (EIL), as a matter of fact, there is an apparent need for integrating technology into English Language Teaching (ELT) education. This need has eventually brought about a new scope for ELT in the form of a new genre: 'Computer Assisted Language Learning' (CALL). Following a Mixed Method Approach, this study investigates some of the issues relating to the use of CALL in the Department of English Language and Literature (ELL) at International Islamic University Chittagong (IIUC). The findings indicate some barriers that seem to impede the integration and the implementation of CALL in the department.
\end{abstract}

Key Words: Educational Technology, Computer Assisted Language Learning (CALL)

\section{Introduction}

Computer Assisted Language Learning (CALL) is relatively a new concept in Bangladesh. Traditionally, English language teaching (ELT) in Bangladesh largely drew upon structural grammar items using the Grammar Translation Method (GTM). However, a recent shift from the GTM to a 'communicative competence' based language education has broadened the scope for ELT in the country.

\footnotetext{
${ }^{*}$ Lecturer, Dept. of English Language \& Literature, International Islamic University Chittagong.
} 
Now the impact of CALL is felt at all the levels of education. At the tertiary level, the shift has the most remarkable impact. In the private university context, ELT has experienced a much wider scope with several language teaching tools, updated materials and methods. Now most private universities are likely to adopt CALL in order to facilitate second language teaching.

This research aims at examining some of the issues involved in the integration and implementation of educational technology in the Department of English Language and Literature (ELL) at International Islamic University Chittagong (IIUC). Educational technology may include a lot of technological aids, for example, computers, projectors, interactive whiteboard, etc. It should, however, be noted that by educational technology here we refer to CALL alone. So, in this paper we use the terms: educational technology and CALL interchangeably. It should also be noted that we do not argue educational technology should replace the previous approaches and methods but it may be used as one of the facilitating tools in the implementation of the approaches and methods in language teaching.

\section{Literature Review}

\subsection{Computer Assisted Language Learning (CALL)}

Even though the definitions of the CALL abound in the literature, for the purpose of this paper we use the definition suggested by Beatty (2003). According to Beatty (2003, p.7), CALL is "any process in which a learner uses a computer and, as a result, improves his or her language". This definition is used here because it exclusively highlights the use of computers for facilitating language learning and teaching, not for using technology just for the sake of technology. There are instances where technology is used as a modern tool in language teaching, but overlooking many other issues in language teaching. We must remember that technology ought to be used as a facilitating tool not as a replacement of other teaching-learning activities.

\subsection{Stage Development of CALL}

From 1960s onwards, the use of CALL has been shaped as per different language learning theories of particular times. Warschauer (1996) divides the expansion of CALL into three phases: 'Behaviorist CALL', 'Communicative CALL' and 'Integrative CALL'. Behaviourist CALL has its inception in the Stimulus-Response theory of Behaviourism. In 
the theory, since learning a language is seen as a matter of habit formation, it is thought that teachers can do that usefully with the help of computers. Hence, in Behaviourist CALL, teachers use the machine to help the learners in practising different drills so that learners get used to different chunks of the language they practise (See Warschauer, 1996).

Communicative CALL emphasizes more on the use of language than its structures (See, Warschauer, 1996). Thus, instead of examining discrete items of grammar, this phase of CALL renders more focus on presenting language in meaningful social contexts. By using computers, learners may have ample opportunities in learning the language from authentic contexts. Integrative CALL, the latest version of educational technology in language teaching, had its origin in the 1990s. It had its impetus from the development of multimedia technology as well as the Internet (Warschauer, 1996). In this phase, language education has become more engaging. The emergence of new technological devices, online communication and the distance learning has made language education more integrative.

\subsection{Issues in the implementation of CALL}

\subsubsection{Advantages}

Computer Assisted Language Learning facilitates foreign-language learning and thus a lot of educational institutions worldwide are likely to integrate CALL in language education. The benefits of the use of CALL may include:

- It has been observed that CALL encourages even lower proficiency level students to participate more actively during lessons, and thus aids the development of linguistic skills (SteppGreany, 2002).

- Use of CALL stimulates learners' active engagement in the learning process; thus, the learning scenario becomes more student-centered (See, Levy, 1997; Ayres, 2002).

- A number of research reports suggest that language learners benefit a lot when they have technological support. CALL raises learners' motivation in language acquisition (See, for example, Stepp-Greany, 2002). 


\subsubsection{Barriers inhibiting the practice of CALL}

Even though the use of technology has a motivating force for learning a foreign language, the impact of CALL on language education has not been as per expectation (See, Bax, 2003; Jones, 2001; Timuçin, 2006). The barriers that inhibit the practice of CALL are:

- Language teachers' attitude towards CALL is an important factor that determines the successful implementation of technology in language education. According to Bax (2003, p. 25), “... most people in language education would recognise that CALL does have a relative advantage, but we are still at the stage where the majority of teachers are nervous of it".

- Implementation of CALL may also be hindered if CALL is introduced without consulting the teachers who will eventually implement it. Also, the implementation of CALL without training the teachers may not be effective (Timuçin, 2006).

- One of the most mentionable hurdles in the implementation of CALL is the lack of enough technological support. In implementing CALL, the availability of necessary instruments is a must. If there is not enough supply of the tools, the CALL seems to have no practical value (Lee, 2000).

- Another barrier inhibiting the implementation of CALL is the lack of teachers' orientation to educational technology (Lee, 2000). Many language teachers do not feel comfortable with high technology as they are not well trained in using it (Jones, 2001).

\subsection{A Case Study}

This section examines a study by Timuçin (2006) investigating why the implementation of CALL in a Turkish State University is unlikely to motivate the learners and teachers in manipulating CALL in language learning.

The university offers a 34-week intensive English language course to students since 1995. Due to wide dissatisfaction with the outcome of the programme, the university decided to adopt CALL. Yet, there were problems in the real integration of CALL, and the programme still lacked innovation. Eventually, a study was carried out examining the reasons why CALL did not yield a positive outcome. The study included 14 teachers having 11 years of teaching experience. The 
result of the research indicated that the teachers' lack of computer skills was the main obstacle to the implementation of CALL. In addition, the teachers were not trained before introducing CALL; rather a new approach was imposed without consulting them.

A post study was conducted after implementing the findings of the previous research. Interestingly, the findings of the second survey revealed that the teachers became more interested and engaged in CALL, and CALL proved to be an innovative approach. Also, at this phase, the teachers' attitudes towards CALL began to change.

The findings of Timuçin's (2006) study indicate that CALL may not be effective if it is imposed on the teachers without training them.

\section{Research Methodology}

The aim of this research, as mentioned before, is to examine some of the issues involved in the integration and the implementation of CALL in the Department of ELL at IIUC. To be specific, the issues that this paper examines are as follows: (a) ELL Teachers' attitudes towards CALL, (b) Teachers' ability in handling Educational Technology, (c) Availability of Technological Supports in ELL, (d) Teachers' Training in CALL. In this study, the respondents are the teachers of the Department of ELL. The study, addresses the following research questions:

1. What attitude do the teachers of ELL hold towards CALL?

2. To what extent are the teachers able to handle educational technology in ELT?

3. To what extent are the teachers satisfied with the availability of technological supports in the department of ELL?

4.Do the teachers in the department of ELL require any training in the use of CALL?

For the purpose of this study, a Mixed-Method Approach is used in order that both quantitative and qualitative data may be gathered. As for the research instrument, a 'Close-ended' survey questionnaire is used. However, there is also an 'Open' question in the questionnaire that allows the participants to share their experiences of and opinions on the issues in the integration and implementation of CALL in the Department of ELL. The participants in this research are the teachers of ELL at IIUC. As for data analysis, the quantitative data are analyzed 
using MS Excel while the qualitative data are coded following Richard's (2003) model. The responding teachers are coded as T1, $\mathrm{T} 2 \ldots \mathrm{T} 12$.

\section{Findings and Discussion}

This section presents the results of this research. The findings are also discussed in this section.

\subsection{Attitudes towards CALL}

Most participants in this research hold a positive attitude towards CALL. $33 \%$ respondents think that CALL is 'very useful' in the English Language Teaching (ELT) programme. 67\% teachers believe CALL is 'useful' in ELT (See Figure 1). In addition, T4 claims "If CALL is implemented in ELL, IIUC students will be benefited immensely". T5 also thinks "...we should give emphasis on video lecture".

However, according to T6, "if technology is used at every step and in everything of the class, the atmosphere of the class may generate monotony for the students'.

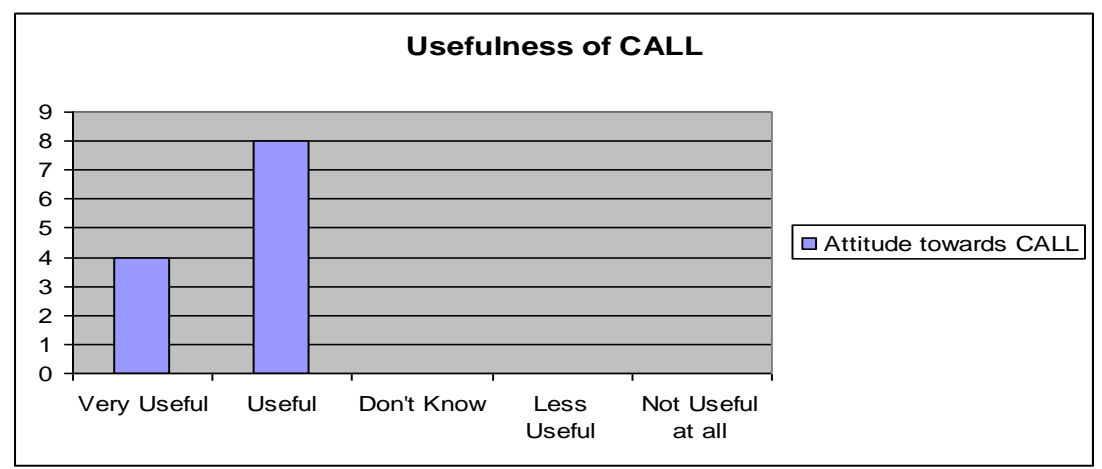

Figure 1: attitude towards CALL

From the above findings, it may be claimed that the teachers in the Department of ELL like the idea of CALL in ELT education. Hence, it is likely that they will appreciate if they have the opportunity and support to implement CALL in ELL.

However, T6 seems to indicate that too much use of CALL may bring about 'monotony' for the learners. Yet, it should be noted here that CALL is advised as one of the facilitating supports in ELT education, not as a replacement of other classroom activities. 
Issues in the Integration of Educational Technology into English Language Teaching Programme: An Empirical Study

\subsection{Teachers' Ability in Handling Educational Technology}

Most of the teachers in the department are able to handle educational technology 'to some extent'. As can be observed from figure 2, most respondents $(67 \%)$ are oriented to handle educational technology 'to some extent', compared to $25 \%$ participants who claim that they are able to handle educational technology 'to a large extent'. 8\% respondents believe that they can handle technology 'a little bit' in ELT education (See figure 2):

Ability to handle Technology

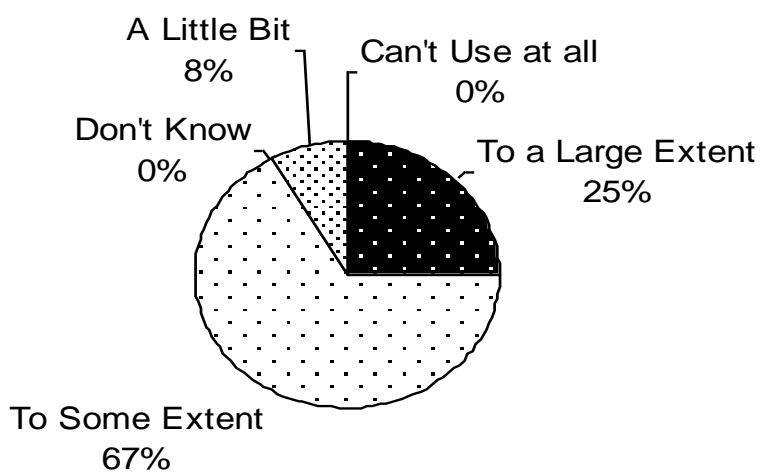

Figure 2: Ability to Handle Educational Technology

From the statistics, it appears that most teachers in ELL department are not well skilled in using technology for ELT. Hence, it is likely that they need some kind of training to handle technology smoothly for the purpose of ELT. T1 also claims 'the teachers are not oriented enough to use information technology in the classroom'. The question of teacher training is further addressed in the research question no. 4 ( $c f .4 .4)$.

\subsection{State of Technological Supports in ELL Department}

As the results illustrate, most teachers in the Department of ELL are not satisfied with the present state of technological supports. 58\% teachers are 'less satisfied', compared to $42 \%$ respondents who are satisfied 'to some extent' over the availability of technological supports in ELL (See figure 3). Yet, for a true integration and implementation of CALL in the Department of ELL, we must ensure the availability of enough technological tools and proper technological supports. 




Figure 3: Technological Supports in ELL

T2, for example, claims that "All classrooms should be well-equipped with tools that are necessary for promoting computer based lesson..." because " ... integration of Educational Technology in ELT depends on availability of materials of technology largely" (T7). T12 suggests that for integrating CALL into ELT there is no alternative to ensuring 'uninterrupted power supply', 'necessary tools' (e.g., enough Computers, Language Labs, Computer Labs, Projectors, CD Players, Video Players, TV, Smooth Internet Connection, etc.) and 'helping hands' (IT Technicians). However, the teachers are found to be less satisfied with the present state of technological supports in the department. T1 argues, "the internet connection is not smooth for the students' while T11 adds 'technological and logistic supports like UPS, sound system, fixed well equipped language labs are rarely available" in ELL at IIUC.

\subsection{Teacher Training in CALL}

Section 4.2 indicated the need for teacher training in CALL. The findings of this section further verify the indication.



Figure 4: Importance of Training in CALL 
As may be observed from Figure 4, most respondents believe that training is a priori in integrating and implementing CALL in language teaching. 68\% teachers think that it is 'very important' for them to have training in CALL, compared to $42 \%$ participants who consider training in CALL as 'important' (See figure 4).

The findings of Section 4.4 suggest that teachers need to have training before integrating and implementing CALL in the Department of ELL in true sense.

\subsection{Discussion and Implications}

From the overall assessment of the findings of this study, it may be indicated that there is a scope for integrating and implementing CALL in the Department of ELL at IIUC. The teachers of ELL department are found to appreciate the idea of CALL and they believe the effective use of CALL can facilitate language learning to a large extent. However, there appear some barriers that constitute hurdles to the proper implementation of CALL in the department. Even though the teachers are willing to adopt CALL in English language teaching, they find it difficult to implement CALL properly as the department has a lack of sufficient technological supports. Also, the teachers themselves need proper orientation and training in CALL if it is to be implemented in real sense.

This research can be linked with a previous research carried out by Timuçin (2006). This study is in line with Timuçin (2006) in that teachers' training in CALL is a priori if we are to integrate and implement it truly. Timuçin (2006) shows that teachers' lack of computer skills is one of the main reasons why CALL is not implemented properly. This study also supports this; the respondents in this study believe that teachers need to be well-trained for implementing CALL in language classroom.

In what this study further contributes to the existing findings is that the lack of available technological supports can also be a hurdle to implementing CALL. Timuçin's (2006) investigation is in Turkey, a developed country. So, in that study there seems to be no problem with the availability of technological supports. But in developing countries, for example, in Bangladesh availability of technological supports is not still smooth. 


\section{Policy Recommendations}

This section tries to manipulate the findings in the context of IIUC with policy recommendations. For a true integration of CALL in the Department of ELL, the following recommendations may be considered as policy prescriptions:

In order to implement CALL, all the classrooms should be wellequipped with the necessary equipment such as, computers, projectors, smooth Internet connection, CD and Video Players, etc.

It has been defined in the IIUC Service Rules handbook that 'human resource is...employed by an organization to achieve the ultimate target or goal of the organization by maximizing the use of other resources' (Chapter-I, Clause A1, p.1). Thus, it is apparent that in order to achieve the goal of the institution by the human resources, we should maximize the use of 'other resources' (e.g., Technological Supports, Internet, Computers, etc.). So, it may be recommended that in order to truly integrate and implement CALL, we should ensure the sufficient availability of 'other resources' (e.g., enough Computers, Language Labs, Computer Labs, Projectors, CD Players, Video Players, TV, Smooth Internet Connection, etc.).

IIUC emphasizes its staff Training. It has also been defined in the IIUC Service Rules handbook that "the University shall organize inhouse training for its employees without disrupting its normal working flow...if the in-house training is not adequate to fulfil the need, the university may organize external training..." (Chapter-I, Clause I, p.12). It is, therefore, recommended that IIUC should arrange "inhouse' and if necessary, 'external' training in CALL for the the teachers in the department. Finally, IIUC should encourage small workshops and seminars on CALL so that the teachers may get oriented with the use of Educational Technology. In that case, the Department of ELL can organize such workshops in collaboration with other institutions. Also, the faculty members who are trained and oriented to the field of educational technology may extend their helping hands in orienting other teachers in the department through seminars and workshops. 
Issues in the Integration of Educational Technology into English Language Teaching Programme: An Empirical Study

\section{Conclusion}

Using a Mixed-Method Approach, this research has investigated some of the issues involved in the integration of CALL in the Department of ELL at IIUC.

As for the findings, it has been observed that though the teachers of the Department of ELL have a positive attitude towards CALL, there appear some barriers that seem to create obstacles to the true integration of CALL in the department. The barriers are: (a) lack of enough technological supports in the department (availability), (b) lack of the teachers' well orientation to technological use (Ability). The findings have also indicated that lack of training is another barrier to implementing CALL in the Department of ELL.

Finally, this paper ends with some recommendations emphasising sufficient availability of technological supports, well-equipped language classrooms, teacher training and departmental seminars and workshops in collaboration with other institutions.

\section{References}

AYRES, R. (2002). Learner Attitudes Towards the Use of CALL. Computer Assisted Language Learning, 15 (3), pp. $241-249$.

BAX, S. (2003). CALL - past, present and future. System, 31 (1) pp. 13 - 28.

BEATTY, K. (2003). Teaching and Researching Computer-assisted Language Learning. London : Pearson Education Limited

IIUC Service Rules Guide (amended version approved by the $148^{\text {th }}$ Syndicate meeting).

JONES, J. F. (2001). CALL and the responsibilities of teachers and administrators. ELT Journal, 55 (4), pp. 360 - 367.

LEE, K. (2000). English Teachers' Barriers to the Use of Computer-assisted Language Learning. The Internet TESL Journal, 6 (12) December, 2000. [online]: http://iteslj.org/Articles/Lee-CALLbarriers.html

LEVY, M. (1997). Computer-Assisted Language Learning: Context and Conceptualization. Oxford: Oxford University Press. 
IIUC Studies, Vol. 10 \& 11

RICHARD, K. (2003). Qualitative Inquiry in TESOL. New York: Palgrave Macmillan.

STEEP-GREANY, J. (2002). Student perceptions of language learning in a technological environment: implications for the New Millennium. Language Learning \& Technology, 6 (1), pp. $165-180$.

TIMUCIN, M. (2006). Implementing CALL in an EFL context. ELT Journal, 60 (3), pp. $262-271$

WARSCHAUER, M. (1996). Computer Assisted Language Learning: an Introduction. In Fotos, S. (ed.), Multimedia language teaching (pp.3-20). Tokyo. Logos International 